\title{
PROMOTIONAL ACTIVITIES IN TOURISM OF REPUBLIC OF KOSOVO
}

\author{
ALBERTA TAHIRI ${ }^{1} \&$ IDRIZKOVACI $^{2}$ \\ ${ }^{1}$ Lecturer at Biznesi College-Prishtina, Kosovo \\ ${ }^{2}$ Faculty of Applied Sciences, Ferizaj, Kosovo
}

\section{ABSTRACT}

The aim of this research is to see what are the strategies for attracting foreign tourists to Kosovo and what the Government of the Republic of Kosovo is doing to attract them. Our goal will be to determine the real situation of this issue, what are its problems, challenges, and opportunities for its further development and performance improvement. The wide interest that exists on this issue is identified with the need of accepting the dynamic nature of the tourist promotion to attract tourists and the tendency to manage the changes that would bring as good results as possible.

When it comes to tourism, it is very important to have an idea and strategy that the state has to offer to foreign visitors and which would be the strategy for attracting the same ones.

The subject of research in this research paper will be analyzing the tactics that Kosovo has to attract foreign visitors. Of particular importance for Kosovo is the fact that Kosovo has a large number of its population that is outside of Kosovo, or rather much of the population has migrated to Western countries.

KEYWORDS: Kosovo, Tourism, Promotion, Promotional Activities \& Promotional Strategies

Received: Feb 19, 2018; Accepted: Mar 09, 2018; Published: Mar 14, 2018; Paper Id.: IJECRAPR20184

\section{INTRODUCTION}

\section{History of Touristic Activities in Kosovo}

Tourism is an economic activity that is oriented to the utilization of tourist potentials. Kosovo, as the youngest state in the world, found the new millennium with a number of challenges as a result of the consolidation process of its statehood. One of them was building a healthy road of sustainable economic development.

In order to realize this, Kosovo must necessarily reveal its potentials and develop strategies for their development. One of these domains is tourism. Its development will affect the rise of the GDP.

Kosovo appeared very late in the tourism market because of the position that it had as part of Yugoslavia and because of its complete isolation due to lack of basic infrastructure. Only after the construction of the Adriatic highway, after1971 Kosovo began to be affirmed as a potential touristic market.

Until 1970, tourism in Kosovo was not developed at all. The basic concept was to develop local tourism. The overall neglect on the basis of tourism influenced the direction of solving those problems, which, among other things was a very acute point of the whole social and economic development. First of all, consideration should be given to the provision of urban environments with accommodation facilities, but also to the constant needs of the population, whether catering or hotel facilities.

After the war, in Kosovo tourism began to develop without having the correct strategy. Kosovo, among other things, was very attractive for foreign visitors because of the fact that it represents a country that emerged from the war. 
During the war, they created many places that at the beginning of the post -war period was attractive to foreign visitors. Usually, these places were the places where happened massive massacres during the war, such as the region of Reçak, the houses of the AdemJashari family in the Drenica etc.

When the situation was put in normal, after the war in the context of tourism, Kosovo concentrated on two dimensions of tourism:

- Cultural tourism and

- Mountain tourism

According to the reports of Ministry of Environment of Kosovo, we can conclude that economy of tourism in Kosovo after the war was in a very difficult situation, because:

- Public sector hotels owned about $70 \%$ of beds in Kosovo, which were very old, in poor condition and not very well equipped,

- Tourism was oriented in transit and business tourism, which is based on prices,

- There was a very small number of visitors in state-owned hotels

- Not once, nor now Kosovo has not built its own touristic image

- The management of hotels is not oriented either in competition nor in a market economy.

- There is a lack of a system of modern communication and information ${ }^{1}$.

- Here we can add some problems that are still present today:

- Weak organization and tourism policy at the national level,

- Poor connection of the tourist offer (lack of attractive touristic product)

- Lack of long-term strategy for socioeconomic development,

- Lack of Kosovo's spatial plan,

- Weak staff training for management and underdevelopment of the management system in hotels and tourist enterprises in Kosovo ${ }^{2}$

- Problems with electricity, water, and waste,

- Destruction of nature and urban centers from illegal buildings,

- Lack of sales channels and cooperation of bidders,

- "Black market"

- A weak interest of investors due to lack of ownership of land disputes, investment opportunities, and their categorization

\footnotetext{
${ }^{1}$ Ministry of Environment of Kosovo, Environmental Report for the Development of Tourism, Prishtina, 2004, p. 11

${ }^{2}$ Ministry of Environment of Kosovo, Environmental Report for the Development of Tourism, Prishtina, 2004, p. 13
} 


\section{The Process of Attracting Foreign Tourists in Kosovo}

Attracting foreign tourists is not a simple thing, especially at a time when travel preferences are constantly changing. The rapid development of society, especially in the last two decades, has significantly changed the behavior of consumers $^{3}$

This has had a tremendous impact on tourism, especially in the area where tourists seek information about travel and stay. Therefore, marketing channels have significantly impacted tourism through an online offer of many products and services. That is exactly one of the biggest problems in Kosovo during the process of attracting foreign visitors.

Another challenge for bringing foreign tourists and creating a strategy for attracting foreign visitors to Kosovo is the lack of official data and statistics. Therefore, data are obtained from different sources in order to have some picture of the industry. This happens, particularly, due to the lack of a common understanding of how different government agencies are related to tourism.

Tourism is financed very little by the government because it is not a priority policy. With limited financial resources, the government cannot afford an appropriate assessment of the potential of tourism, promotion and strategy creation, studies to develop strategic attractiveness plans,etc. However, this shortfall is offset somewhere by the international funds provided by various donors that support a number of tourism development projects.

\section{Promotion of Kosovo in World Fairs of Tourism}

Promotion is one of the main tools for attracting foreign tourists. There are several classifications of the tourism promotion, which are realized according to different criteria.

\section{According to the Spatial Coverage and Who is the Carrier of the Tourist Promotion we have}

1. General tourism promotion - carried out by state or social authorities. It is an important instrument for economic and tourism policy. The main goal of the tourist promotion is to stimulate interest and desire for visiting and staying in a certain area.

According to the size of the space we are propagating, we distinguish:

- Local tourist promotion (municipality, tourist place, national park, locality)

- $\quad$ Regional tourist promotion (region)

- National tourist promotion (country)

- Multinational tourist promotion

2. Commercial touristic promotion (business touristic promotion) where specific tourist objects are propagated, or certain tourism products /services (eg accommodation in a hotel, transport, food, entertainment...). This is the most important instrument for conducting the business policy of tourist promotion. It is organized by tourist agencies or specialized institutions for economic promotion.

${ }^{3}$ Mills, J. \& Law, R. (2004). Handbook of Consumer Behaviour, Tourism and the Internet. New York: Harworth Hospitality Press. 


\section{According to the Holders of the Tourist Promotion we Distinguish}

- An Individual tourism promotion where only one promoter of propaganda action appears and

- A Collective tourist promotion where we have a joint promotional activity of several carriers

\section{According to the Market Orientation we have}

- Domestic tourism promotion and it is an instrument for achieving the goals that tourism policy wants to achieve on the domestic tourism market and

- The foreign tourist promotion, which is an instrument for achieving the goals that tourism policy wants to achieve on the international tourism market

\section{According to the Content of the Tourist Promotion we have}

- Global (institutional) tourist promotion, where are specified the general attractions of a tourist place, region or country

- Special (specific) tourist promotion where only the attractive features of the area (cultural and historical monuments, cultural and sporting events) are highlighted, or information on prices and quality etc.

In the research for the idea of promoting Kosovo in the world's fairs, it can be seen that Kosovo backwards participates in various tourist fairs. The first participation in such a single participation in the fair of Istanbul, then in Berlin, and the last participation is at the tourism fair in Paris, France.

The Ministry of Trade and Industry, the Agency for Investment and Support of Enterprises in Kosovo (KIESA), are the main bearer participating in such fairs, in order to promote the tourism and tourist values that Kosovo offer. At the last fair, they were together with local tour operators, which was realized, as we said, at the Fair of Tourisme "Destination Nature" in Paris, France.

In this fair, Kosovo's promotional strategy was promoting natural beauties, Kosovo's cultural heritage, and various activities such as walking and hiking in order to catch the attention of many visitors.

According to the official statements, for Kosovo during this fair tour operators have shown significant interest in Kosovo as a tourist destination.

The "Destination Nature" fair is one of the most important tourism trade fairs, especially in the activities of travel and wildlife.

\section{CONCLUSIONS}

In this paper, we tried to determine the strategies for attracting foreign tourists in Kosovo and what the Government of the Republic of Kosovo is doing to attract them. The basic assumptions in this paper were that the Government of Kosovo has not developed an accurate strategy for attracting tourists. On the other hand, attracting foreign tourists is directly related to the need to realize promotional activities of tourism in Kosovo, which are also not satisfactory.

The research showed us that there is no special document that accurately defines a strategy for attracting foreign tourists. 
An important document is the analysis of the profile of the tourism sector published by MTI. It is worth mentioning that Kosovo does not have a separate Ministry of Tourism, but it functions within the Ministry of Trade and Industry of the Republic of Kosovo.

Kosovo has a lack of official data and statistics. Therefore, data are obtained from different sources in order to have some picture of the industry. This happens, in part, from the lack of a common understanding of how different government agencies are related to tourism. This is one of the basic problems, why Kosovo cannot have a strategy to attract tourists.

Tourism is not considered as a priority sector for development and its impact on Kosovo's economic development will continue to be limited. Tourism is governed by a law passed by the central government, but there is no development strategy. At the same time, responsibility for this sector lies within the Ministry of Trade and Industry, and is managed by only three officers who make up the Tourism Department.

These are the reasons why Kosovo has not developed a separate strategy for attracting tourists. Therefore, as a major recommendation is that Kosovo should try to develop a strategy for attracting foreign visitors in the shortest possible time frame. The reasons are great. In the first place, the strategy should be in the function of attracting primarily the migrant workers, who develop every day concepts to spend most of the annual holidays at sea, instead of spending on their fatherland. This translation would mean fewer remittances and fewer inflows for the Kosovo economy.

\section{REFERENCES}

1. Këshilli i Evropës, Dilemë: përdorimi i trashëgimisëkulturorepërturizëmaposhfrytëzimi i turizmitpërmbrojtjendhemirëmbajtjen e trashëgimisëkultrore

2. FatosUkaj, Koncepti i MarketingutsiMjetpërZhvillimin e TurizmitnëKosovë, 2010

3. Instituti GAP, Ndikimiekonomik i Dokufestit, 2011

4. Strategjiapërpromovimin e investimeve e AgjencisëpërPromovimin e InvestimevenëKosovë 2011-2013

5. IPVQ, Ministria e TregtisëdheIndustrisë, Raporti i zhvillimithapësinorpërsektorin e turizmit, 2004

6. Republika e Kosovës, Agjencia e StatistikavetëKosovës, BrutoProdhimi Vendor sipasveprimtariveekonomike (2006 - 2011), 2012

7. Republika e Kosovës, Agjencia e StatistikavetëKosovës, Statistikatëhotelerisë, 2013

8. Republika e Kosovës, Ministria e TregtisëdheIndustrisë, InvestonëKosovë, 2011

9. ValdeteRexhepi, TurizmidheObjektivat e ZhvillimittëMijëvjeçarit: Rastistudimor i Kosovës, 2012

10. Александат Цицковски, Промотивни активности во угостителско - туристичките претпријатија

11. Лидија Симонческа, Пормотивни активности во туризмот, Охрид, 2011 
